\title{
The distribution of the $P-M$ system in Drosophila melanogaster strains from the People's Republic of China
}

\author{
D Anxolabéhère ${ }^{1}, \mathrm{~K} \mathrm{Hu}^{2}$, D Nouaud ${ }^{1}$, G Périquet ${ }^{3}$ \\ ${ }^{1}$ Université Pierre et Marie Curie, mécanismes moléculaires de la spéciation, \\ 4, Place Jussieu, 75005 Paris; \\ ${ }^{2}$ University of Hainan, Biology Center, 570001, Hainandao, \\ People's Republic of China; \\ ${ }^{3}$ Faculté des Sciences, institut de biocénotique expérimentale \\ des agrosystèmes, Parc Grandmont, 37200 Tours, France
}

(Received 20 June 1989; accepted 22 February 1990)

Summary - An extensive survey of the $D$ melanogaster populations collected during the period 1982-1987 in the People's Republic of China was carried out with respect to the P-M system of hybrid dysgenesis. Geographical differentiation was found between the continental area where only the $\mathrm{M}^{\prime}$ type occurs, and the coastal areas, where the populations were characterized as weak $P$ or $Q$ types. All populations studied carried $P$ sequences and had a high frequency of the KP element (a particular $P$ element deletionderivative). The geographical differentiation of eastern Asian populations appears to be a mirror image of that of western Eurasian populations with the highest frequencies of $P$ elements existing in the coastal areas. The causes of this geographical differentiation are discussed.

Drosophila melanogaster / geographical distribution / mobile elements

Résumé - Distribution des caractéristiques du système $P-M$ de dysgénésie des hybrides dans des souches de Drosophila melanogaster collectées en République populaire de Chine. Nous présentons une analyse des caractéristiques génétiques et moléculaires du système $P-M$ de dysgénésie des hybrides de 39 populations de D melanogaster collectées en République populaire de Chine au cours de la période 19821987. Il existe une différenciation géographique marquée entre la région continentale, où les populations sont de type $M^{\prime}$, et les régions côtières dans lesquelles les populations sont principalement de type $P$-faible ou $Q$. Toutes les populations étudiées présentent des séquences $P$ et une fréquence élevée d'éléments $K P$ (une sous-famille d'éléments $P$ dérivée de l'élément $P$ autonome par une délétion interne spécifique). Vis-à-vis du système $P-M$, la différenciation géographique des populations orientales de l'Eurasie se présente comme une image en miroir de celle des populations occidentales, avec les plus hautes fréquences d'éléments $P$ sur les régions côtières. Les causes de cette différenciation géographique sont discutées.

Drosophila melanogaster / distribution géographique / éléments mobiles 


\section{INTRODUCTION}

In the $P-M$ system of Drosophila melanogaster, the syndrome of hybrid dysgenesis (inducing gonadal sterility, high mutation level, etc...) is known to be related to the activity of the $P$ element family of transposons (Engels, 1989). $P$ element structures can be classified into 2 broad types: autonomous (complete) elements of $2.9 \mathrm{~kb}$, and non-autonomous elements that usually have substained internal deletions of varying sizes.

Strains of Drosophila may be characterized on the basis of 2 properties related to the phenotypic effects of their $P$ elements. Strains are specific in their ability to mobilize $P$ elements that are in an unregulated state. This ability is referred to as " $P$ activity potential". Strains may also vary in their property to regulate or suppress the activity of the autonomous $P$ elements present in their genomes. This property is referred to as " $P$ susceptibility". It covers the joint action of all mechanisms affecting $P$ element regulation, including that of cytotype (Engels, 1979).

Based on these properties, strains may be classified into 4 broad types, according to their phenotypic characteristics in diagnostic test crosses and the number of $P$ elements they possess. $P$ strains have low to high levels of $P$ activity potential. In addition, they also have low levels of $P$ susceptibility. $Q$ strains have extremely low levels of both $P$ activity potential and $P$ susceptibility ( $<5 \%$ of induced gonadal sterility) (Kidwell, 1979). Individuals of the $P$ type or of the $Q$ type the have 25-60 copies of $P$ sequences (complete and/or deleted) per haploid genome (Bingham et al, 1982). $M$ and $M^{\prime}$ strains rarely have any significant level of $P$ activity potential. $M$ strains are devoid of any $P$ elements and have extremely high $P$ element susceptibility. $M^{\prime}$ strains carry $P$ sequences, from a few up to 50 copies per haploid genome. Most, if not all of these sequences are defective (Bingham et al, 1982; Black et al, 1987; Izaabel et al, 1987). $M^{\prime}$ strains vary for $P$ element susceptibility from extremely high to moderately low (Anxolabéhère et al, 1985). A subtype of $M^{\prime}$ strains, harbouring several copies of a specific deletion derivative element (the KP element) has also been described (Black et al, 1987). These $K P$ elements may interact, perhaps by inhibition of the transposase of active elements, to repress the level of induced hybrid dysgenesis.

Genetic and molecular data from long established laboratory strains provide strong evidence in favor of a recent invasion of the genome of $D$ melanogaster by $P$ transposable elements (Kidwell, 1983; Kidwell et al, 1983; Anxolabéhère et al, 1988).

Surveys of natural populations have shown pronounced geographical differences (Anxolabéhère et al, 1982, 1984; Kidwell, 1983; Boussy, 1987; Boussy and Kidwell, 1987). $P$ strains predominate in the Americas and Central Africa, whereas $M^{\prime}$ strains predominate in Europe, North Africa and Asia. In Eurasia, a gradient has been shown to occur from western Europe, where most strains are $Q$, to the mid-Asian area where $M^{\prime}$ strains predominate (Anxolabéhère et al, 1985). These large differences in $P-M$ characteristics between inter and intra continental areas are consistent with the hypothesis of a worldwide $P$ element invasion of the $D$ melanogaster genome and suggest that the Americas were invaded before Europe, Africa and the rest of the world (Anxolabéhère $e t a l, 1988$ ). If this is the case, natural 
populations of $D$ melanogaster may offer us the opportunity to study the dynamics of a transposable element through the genome of a species recently invaded by it.

In this paper we report a genetic and molecular analysis of more than 40 strains collected from natural populations in China during the 1982-1987 period. The geographical differentiation of the eastern Asian populations appears to be a mirror image of that of western Eurasian populations, with the lowest frequencies of $P$ elements found in the populations from the central part of China and the highest frequencies of $P$ elements in populations from the east coastal part.

\section{MATERIALS AND METHODS}

\section{Strains studied}

Forty-one wild strains collected in diverse areas of China (fig 1) were investigated in this study. Each strain was derived from a large number $(>30)$ of individuals collected in 1982-1983 (21 strains) and in 1984-1987 (20 strains). They were kept under standard laboratory conditions by mass culture. Two series of genetic tests were performed, one in 1984 and the other in 1988. The molecular analysis was performed in 1987.

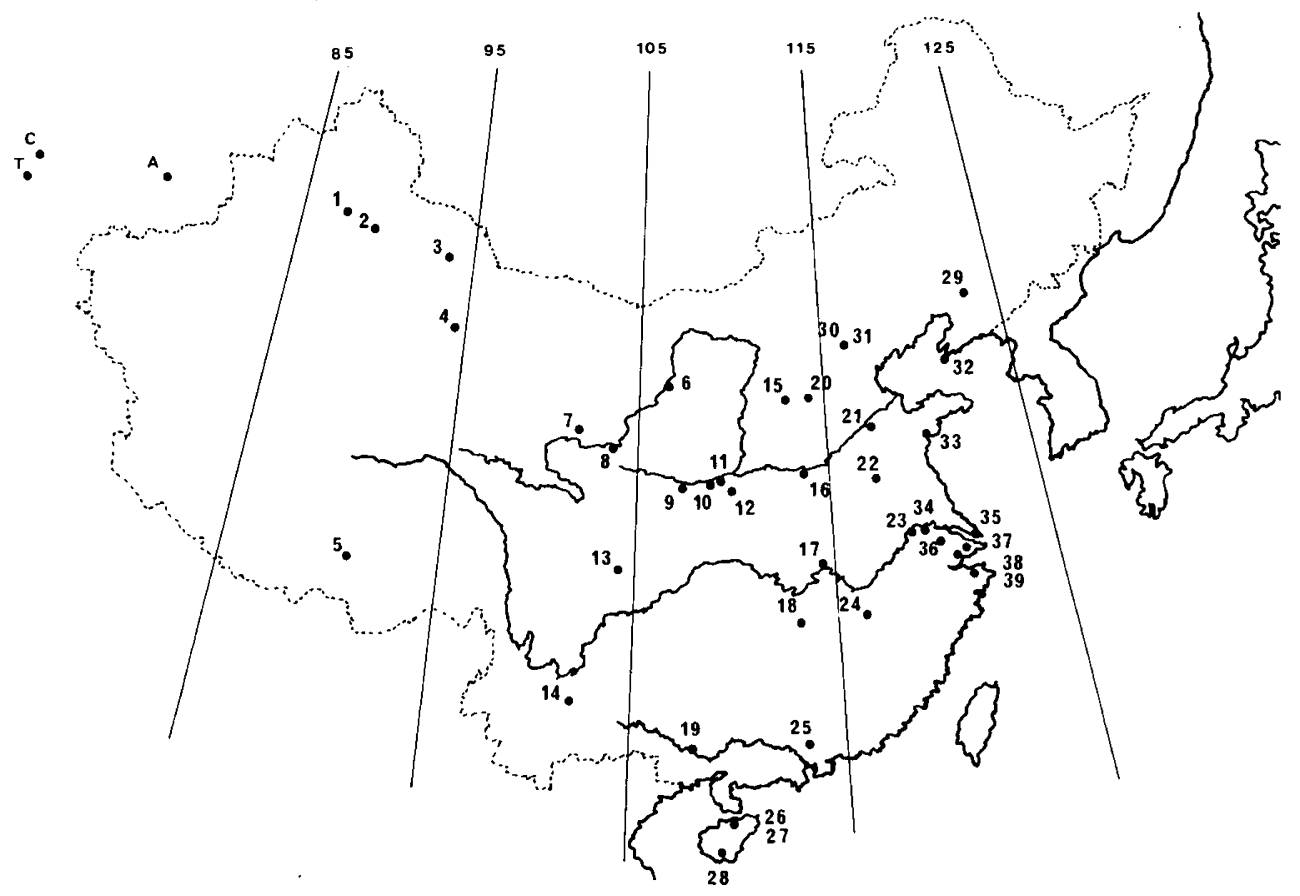

Fig 1. Geographical origin of strain collected in the People's Republic of China. (The numbers are defined in table I, and $T$ : Tashkent, $C$ : Chimkent, $A$ : Alma-Ata, are localities in the USSR.) 


\section{Classification of strains}

Two reference strains were used to determine the $P-M$ status of wild strains: Harwich, a strong $\mathrm{P}$ reference strain, and Canton-S an M reference strain (Kidwell et al, 1977). The diagnostic tests used were the standard tests measuring gonadal sterility (GD sterility) potential (Kidwell, 1983): cross A, Canton-S females $\times$ males of tested strain, and cross $\mathrm{A}^{*}$, females of tested strain $\times$ males of Harwich strain. For each cross, 15-30 pairs of flies were crossed in half-pint bottles and immediately allowed to develop at $29^{\circ} \mathrm{C}$. Approximately $2 \mathrm{~d}$ after the onset of eclosion, $\mathrm{F}_{1}$ progeny were collected and allowed to mature for $2 \mathrm{~d}$ at room temperature. At least 50 females were then taken at random for dissection. The frequency of GD sterility was calculated by dividing the number of dysgenic gonads by the total of gonads scored. The rate of GD sterility in cross A provided a measure of the $\mathrm{P}$-activity potential of the strain under test; in cross $\mathrm{A}^{*}$ it provided a measure of P susceptibility.

\section{Molecular analysis}

Three methods of molecular analysis were used in order to characterize the strains for their qualitative and quantitative $P$ elements composition: 1 ) the squashed-blot method (Tchen et al, 1985) to detect the presence of $P$ element sequences in single flies, 2) in situ hybridization to estimate the $P$ element copy number per haploid genome, 3) the Southern blot method to characterize the complete or defective $P$ elements.

The presence of $P$ element sequences was detected by using the squash blot technique on 10 individual females per strain, crushed on a nylon filter membrane treated and hybridized with $P$ element restriction fragments following the procedure of Anxolabéhère et al (1985). The probe consisted of the 2 restriction fragments $\left(\mathrm{P}_{1}\right.$ and $\mathrm{P}_{2}$, fig 2) from the $\mathrm{p} \pi 25.1$ plasmid (O'Hare and Rubin, 1983) eluted from agarose gel by the squeeze freeze technique (Tautz and Renz, 1983) and purified by Gene Clean (BIO 101). $\mathrm{P}_{1}$ contains the $0.84 \mathrm{~kb}$ Hind III restriction fragment, of the complete $P$ element. Because this fragment is located at the left-hand end, most of the $P$ elements, including the defective ones, are expected to possess at least some of the $\mathrm{P}_{1}$ sequence. $\mathrm{P}_{2}$ contains the internal $1.5 \mathrm{~kb}$ Hind III/Sal I restriction fragment of the $P$ element. Because of its location, many defective $P$ elements are expected to lack all or part of the $\mathrm{P}_{2}$ sequence.

$P$ element copy number was measured by in situ hybridization to polytene chromosomes of a tritium dCTP-labelled probe: the $\mathrm{p} \pi 25.1$ plasmid (O'Hare and Rubin, 1983) containing the full-length $P$ element plus genomic DNA from the $17 \mathrm{C}$ region. In order to determine the copy number per haploid chromosome complement, females of the tested strain were crossed with Gruta strain males (the Gruta strain is devoid of $P$ elements) and the squash procedure was performed on 3 to $5 \mathrm{~F}_{1}$ larvae. The $17 \mathrm{C}$ label was used as a hybridization positive control and, of course, was not counted.

The structure of the $P$ sequences present in some specific strains was analyzed by Southern blots in order to test for the presence of complete $P$ elements and particular deleted $P$ elements. DNA was extracted from 100 flies per strain using the method described by Junakovic et al (1984). Restriction enzyme digestion of 


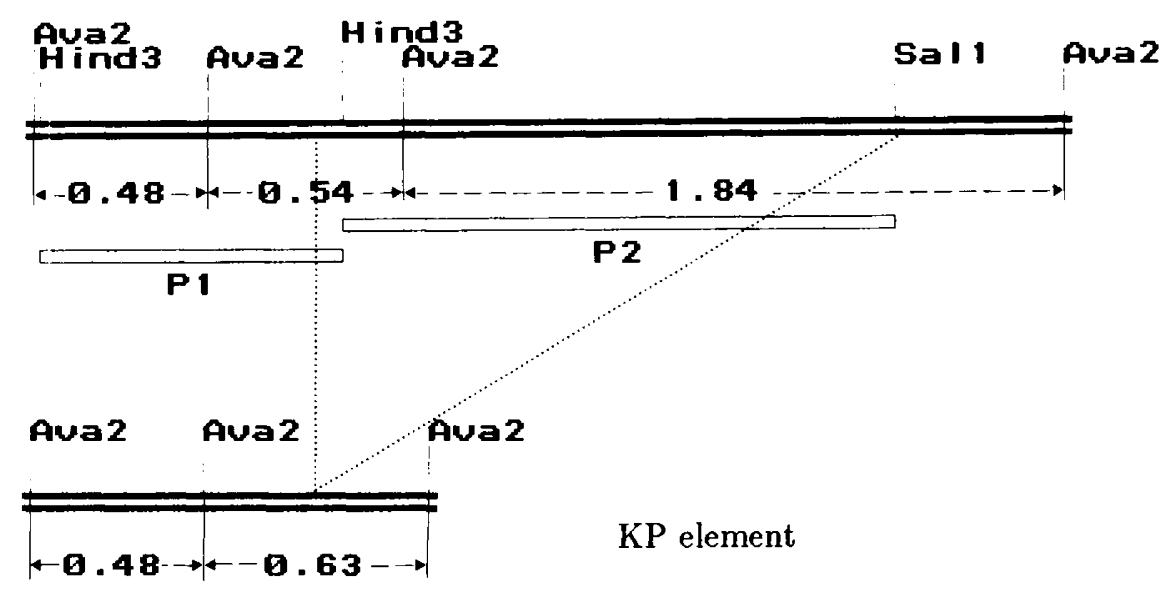

Fig 2. Restriction map of the complete $P$ element, showing the structure of $\mathrm{P}_{1}$ and $P_{2}$ probes, and of the $K P$ element.

about $5 \mu g$ of DNA was performed according to the manufacturers instructions, and Southern blots were performed using standard techniques (Maniatis et al, 1982). Filters were washed at high stringency $\left(0.1 \times S S C, 0.5 \% S D S ; 65^{\circ} \mathrm{C}\right)$. Uncut $p \pi 25.7 B W C$ ("both wing clipped") was used as a probe. $p \pi 25.7 B W C$ plasmid contains a $P$ element that lacks $39 b p$ from its $5^{\prime}$ end and $23 b p$ from its $3^{\prime}$ end. All the genomic sequences that flank the complete element in the original $p \pi 25.7$ plasmid, as well as some of the $p B R 322$ sequences, were removed in the process of making $p \pi 25.7 B W C$.

\section{RESULTS}

\section{$P-M$ status of Chinese populations}

The rates of $G D$ sterility in tests for $P$ susceptibility (cross $A^{*}$ ), $P$ potential activity (cross $A$ ) and intrastrain $G D$ sterility are presented in table I. The 39 localities studied were grouped into 2 areas using the 115th East meridian to define western and eastern populations. The populations were classified according to their geographical position and their level of $P$ susceptibility using the criterion of $50 \%$ of $G D$ sterility in the females from the $A^{*}$ diagnostic test (table II). The observed differences are statistically significant $\left(\chi^{2}=22.6,1 d f, P<0.001\right)$ showing that western populations have higher $P$ susceptibility than eastern ones. Since low or no significant $P$ activity potential was detected in any of the populations sampled, western populations may be classified as being mainly of the $M$ type and eastern ones of weak $P$ or $Q$ type. Intrastrain $G D$ sterility is low for all strains, suggesting that there is very little hybrid dysgenesis in Chinese populations. However, in some populations with a high $P$ susceptibility an erratic rate of 
Table I. Phenotypic and molecular characteristics of strains collected in the People's Republic of China during the 1980s.

\begin{tabular}{|c|c|c|c|c|c|}
\hline Strain & $\begin{array}{c}P \text { susceptibility } \\
\text { Cross } A^{*}\end{array}$ & $\begin{array}{c}P \text { activity } \\
\text { Cross } A\end{array}$ & $\begin{array}{l}\text { Intrastrain } \\
\text { sterility }\end{array}$ & $\begin{array}{l}\text { Level } \\
\quad P_{1}\end{array}$ & $\begin{array}{l}\text { ridization } \\
P_{2}\end{array}$ \\
\hline 1 Urumqi 83 & 98 & 3 & 0 & 3 & 1 \\
\hline 2 Turfan 83 & 100 & 3 & 0 & 3 & 2 \\
\hline 3 Hami 84 & 88 & 3.5 & 4 & 3 & 2 \\
\hline 4 Dunhuang 84 & 96 & 4 & 3 & 3 & $\hat{I}$ \\
\hline 5 Lhassa 83 & 100 & 5.5 & 2 & 3 & 1 \\
\hline 6 Yinchuan 84 & 90 & 1 & 4 & 4 & 3 \\
\hline 7 Xining 84 & 92 & 4 & 1 & - & - \\
\hline 8 Lanzhou 84 & 94 & 5 & 2 & 4 & 3 \\
\hline 9 Meixan 82 & 99 & 0 & $=$ & 3 & 1 \\
\hline 10 Xian 84 & 92 & 6 & 0 & - & - \\
\hline 11 Lintong 82 & 87 & 0 & 0 & - & - \\
\hline 12 Shangluo 84 & 76 & 0 & - & 3 & 1 \\
\hline 13 Chengdu 83 & 100 & 3.5 & 1 & 4 & 3 \\
\hline 14 Kunming 82 & 62 & 0 & 0 & - & - \\
\hline 15 Taiyuan & 88 & 6 & 2 & 4 & 3 \\
\hline 16 Zengzhou 84 & 74 & - & 2 & - & - \\
\hline 17 Wuhan 83 & 88 & 4 & 0 & 4 & 3 \\
\hline 18 Changsa 82 & 86 & 0 & 0 & - & - \\
\hline 19 Nan Ning 83 & 98 & 3.5 & 0 & 4 & 3 \\
\hline 20 Shijiazhuang & 39 & 1.5 & 0 & 4 & 2 \\
\hline 21 Jinan 82 & 22 & 0 & 1 & 4 & 3 \\
\hline 22 Xuzhou 83 & 100 & 1.5 & $\overrightarrow{1}$ & 4 & 3 \\
\hline 23 Nanjing 82 & 43 & 0 & 0 & 4 & 3 \\
\hline 24 Nanchang 85 & 19 & 0 & - & 4 & 4 \\
\hline 25 Guangzhou 84 & 100 & 1 & 4 & 4 & 2 \\
\hline - Guangzhou 85 & 96 & 4.5 & - & 4 & 3 \\
\hline - Guangzhou 86 & 98 & 0.5 & - & 4 & 3 \\
\hline 26 Honghu 87 & 98 & 1.5 & - & 2 & 1 \\
\hline 27 Haikou 85 & 32 & 0 & - & 4 & 2 \\
\hline 28 Tongza 86 & 46 & 0 & - & 3 & 1 \\
\hline 29 Shenyang 83 & 28 & 5.5 & 0 & 5 & 4 \\
\hline 30 Beijing 82 & 2 & 1 & 0 & 4 & 2 \\
\hline 31 Xiangshang 87 & 2 & 1 & - & 3 & 2 \\
\hline 32 Dailian 83 & 4 & 11 & 2 & 4 & 3 \\
\hline 33 Qindao 84 & 3 & 0 & 2 & 5 & 4 \\
\hline 34 Zhenjing 82 & 0 & 0 & 0 & 4 & 4 \\
\hline 35 Chougmin 83 & $\ddot{6}$ & 9 & 0 & 5 & 4 \\
\hline 36 Wuxi 82 & 18 & 0 & 0 & 5 & 4 \\
\hline 37 Shangai 84 & 90 & 0 & 4 & 4 & 3 \\
\hline 38 Jinghua 83 & 2 & 2 & 0 & - & - \\
\hline 39 Zenhai 84 & 5 & 0 & - & 4 & 4 \\
\hline
\end{tabular}

$G D$ sterility was detected in some $A$ crosses (the populations 5,8 and 10); as no intrastrain $G D$ sterility occurs in these populations, this $G D$ sterility might correspond to a very low $P$ potential activity.

The results of the squash blot tests are shown in fig 2 . All the flies tested gave a positive signal with the $P_{1}$ and $P_{2}$ probes, revealing the presence of $P$ element 
Table II. Distribution of western and eastern populations according to their level of $P$ susceptibility.

\begin{tabular}{lccc}
\hline & \multicolumn{2}{c}{$G D$ sterility level } & $\Sigma$ \\
\hline & $>50 \%$ & $<50 \%$ & \\
\hline Western populations & 23 & 3 & 26 \\
Eastern populations & 2 & 13 & 15 \\
$\Sigma$ & 25 & 16 & 41 \\
\hline
\end{tabular}

hybridizing DNA sequences in all 39 strains. Six levels of signal intensity were established, from 5 to nul. 5 was equivalent to the signal intensity of the positive control strain Harwich; 0 was equivalent to complete absence of hybridization, as seen in the negative control strain Gruta. In all the Chinese strains, except for 3 the intensity level was weaker with the $P_{2}$ probe than with the $P_{1}$ probe, a difference not shown with the Harwich control (table I). This suggests the presence of numerous $P$ element deletion-derivatives in these populations.

Furthermore, differences appear between western and eastern populations according to the signal they give (fig 3 ). Strains showing a weak homology with $\mathrm{P}_{1}$ and especially with $\mathrm{P}_{2}$ probes are mainly from the most inland areas. This result could be due either to some differences of homology between the probes used and $P$ sequences in these populations, or the presence of a different number of $P$ copies per genome.

In order to test this geographical differentiation, a sample of 5 strains taken in the inland and 5 in the costal areas was analyzed by in situ hybridization (table III). The $P$ copy number per haploid genome is high in Chinese populations and as expected, data from the squash blot method were confirmed: $P$ copy number is clearly the highest in populations from coastal areas.

Table III. Number of $P$ copies per haploid genome in inland and coastal populations of the People's Republic of China (mean of 3 larvae).

\begin{tabular}{lcclc}
\hline \multicolumn{2}{c}{ Inland strains } & & \multicolumn{2}{c}{ Coastal strains } \\
Strain & $P$ copy number & & Strain & $P$ copy number \\
\hline 1 Urumqi & 23.1 & 24 & Nanchang & 35.2 \\
4 Dunhuang & 23.4 & 31 & Xiangshang & 23.0 \\
6 Yin Chuan & 25.3 & 33 & Qindao & 36.4 \\
12 Jinan & 21.2 & 34 & Zhenjing & 27.9 \\
14 Kunming & 12.8 & 35 & Chougmin & 45.1 \\
\hline
\end{tabular}

\section{Southern blot analysis}

In an attempt to determine the type of $P$ elements present, genomic Southern blots were performed with AvaII endonuclease on some continental and coastal 


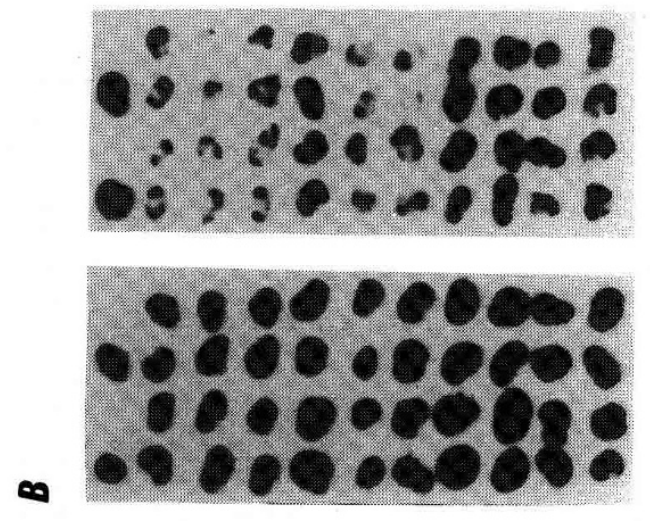

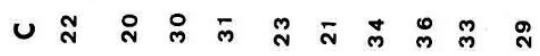
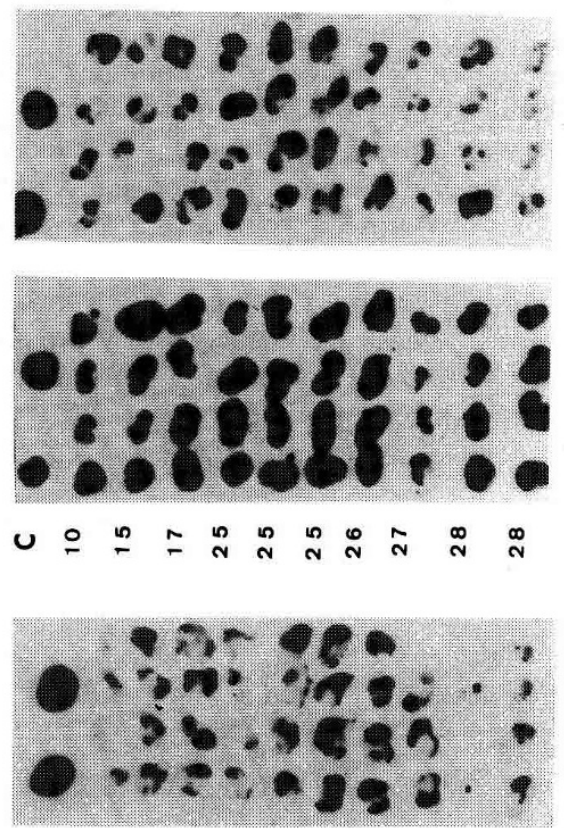

a

ก

素常

茟苞

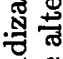

㟧

$\Sigma$

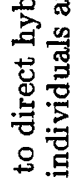

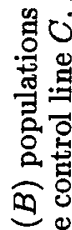

돈

ก

ฐ

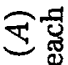

焉

$\Sigma$

要

要

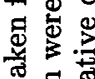

要营莺

胥筞

矛苟

N

总害

드윰

원옹 용

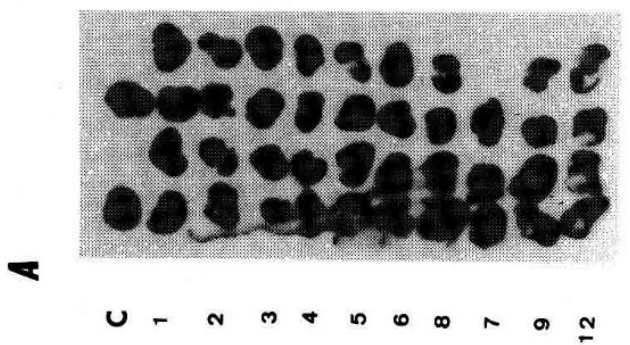

红 † ㄴㅇㅇㅇㅇㅇ 总点

-

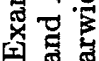
के

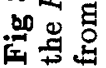


populations. AvaII cuts a full-sized $P$ element at 4 sites to generate 3 internal fragments of $0.48,0.54$ and $1.84 \mathrm{~kb}$ in lenght. The $K P$ element (a particular $P$ element deletion-derivative, Black et al, 1987) is cut at 3 sites generating internal fragments of 0.48 and $0.63 \mathrm{~kb}$ length (fig 2). Fig 4 shows AvalI digests of genomic DNA from several populations collected from the western continental area through to the east coast (fig 4a) and others collected from North to South among the coastal populations (fig $4 \mathrm{~b}$ ), hybridized to the $p \pi 25.7 B W C$ probe. The 1.8 and $0.54 \mathrm{~kb}$ fragments, representing full-sized $P$ elements, are irregularly detected with various signal intensities. The signal intensity given by the $0.63 \mathrm{~kb}$ band representing the $K P$ element is very strong and is present in all the populations tested. The 0.48 $\mathrm{kb}$ band can be generated by the full sized $P$ element, the $K P$ element and other elements not deleted in the 22-500 region. However, the weakness of the signal intensity of the $0.54 \mathrm{~kb}$ band, which corresponds to the full-sized $P$ element, and the relative lack of bands at positions other than $1.8,0.63$ and $0.54 \mathrm{~kb}$ indicate that the $0.48 \mathrm{~kb}$ band is mainly due to the $K P$ element. From these results, the $K P$ element seems to be present at a high frequency in these populations.

a
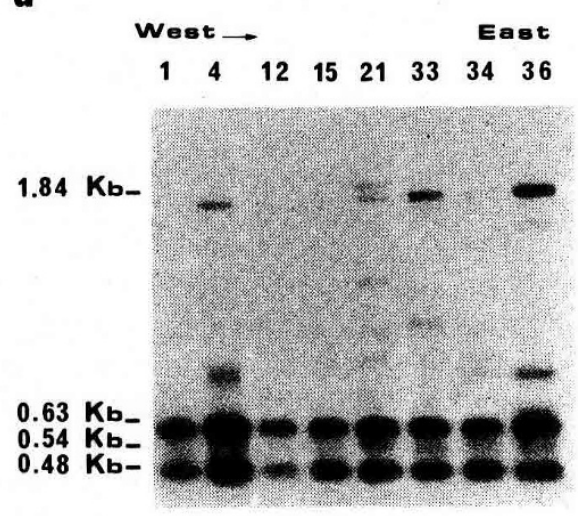

b

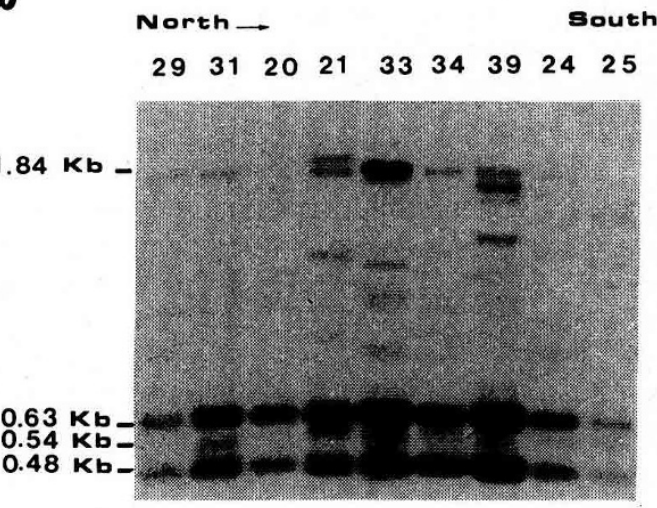

Fig 4. Autoradiogram of AvaII digests of genomic DNA from some Chinese populations probed with the complete $P$ element $(\mathrm{p} \pi 25.7 B W C)$. The expected internally-derivated AvaII restriction fragments are indicated: $0.48 \mathrm{~kb}$ ( $P$ and $K P$ elements), $0.54 \mathrm{~kb}$ ( $P$ element), $0.63 \mathrm{~kb}$ ( $K P$ element) and $1.8 \mathrm{~kb}$ ( $P$ element). a: localities ranged from west to east. b: coastal populations ranged from north to south. The numbers correspond to the localities defined in table I.

Genomic digests of DNA from populations collected in the central part of the coast $(21,33,34,36$ and 39$)$ seem to indicate more $P$ sequences, and especially the putative complete $P$ element, than other Chinese populations. These results are in accordance with those from the in situ analysis and the GD sterility occurring in cross $A$ and cross $A^{*}$ tests. 


\section{DISCUSSION}

Our analysis indicates that the current Chinese populations of $D$ melanogaster contain in their genome numerous $P$ element sequences and that they are $M^{\prime}, Q$ or weak $P$ types in the $P-M$ system of hybrid dysgenesis. The high $P$ susceptibility levels of the strains collected in the western part of China contrast with the ability of the strains from the coastal area to suppress $P$ activity. The presence of the $M^{\prime}$ type populations in inland China and the $Q$ type along the eastern coast is in accordance with previous surveys of the $P-M$ properties in natural populations performed during the eighties, showing the occurrence of $M^{\prime}$ types in Eurasian populations (Anxolabéhère et al, 1985; Ronsseray et al, 1989; Périquet et $a l, 1989), M^{\prime}$ and $Q$ type in Korean populations (Paik, 1988) and the predominance of the $Q$ type in Japanese populations (Todo et al, 1984; Yamamoto et al, 1984). Molecular investigations of the Chinese populations in which genomic DNA was extracted and probed with the full-sized $P$ element revealed that complete $P$ elements are irregularly present, and are found most frequently in coastal populations. Conversely, all of these populations contain numerous $K P$ elements, but no geographical differentiation has been detected. The presence of $K P$ elements in Chinese populations confirms the fact that this specific defective $P$ element is widespread in natural populations, especially in Eurasia (Black et al, 1987; Ronsseray et al, 1989; Périquet et al, 1989) and in Australia (Boussy, 1987; Boussy et al, 1988).

In a previous study, Périquet et al (1989) showed that the frequency of $P$ elements gradually decreases from France to central Asia. Strains collected in 1981-1983 on the west side of a border zone between the USSR and the People's Republic of China (PRC) carried a small number of $P$ copies per genome: Tashkent 13.8, Chimkent 8.8 and Alma-Ata 7.7. A clear difference was found in the present study: the $P$ copy number per genome in strains from the Chinese side of this border zone was significantly higher: Urumqi 23.1 and Dunhuang 23.4. This difference probably reflects the absence of migration between these 2 areas due to a geographical barrier: the very high mountains of the Tien Shan. Our squashed blot and in situ analyses clearly show that the geographical differentiation of Chinese populations is a mirror image of that of western Eurasian populations. Taking all the data into account, there is a clear division in the distribution of characters in the $P-M$ system in Eurasia, ranging from France to China. The $P$ copy number, and the frequency of weak $P$ or $Q$ strains is higher in western Europe and eastern China, with $M^{\prime}$ strains, which show the lowest $P$ copy number, being present in the central area.

Molecular analysis of $P$ homologous elements in numerous species of the Drosophilidae family (Anxolabéhère and Périquet, 1987) have revealed the presence of $P$ elements in Drosophila melanogaster, but not in its various sibling species. The findings of $P$ homologues in more distantly related species (Daniels and Strasbaugh, 1986) and, more recently, of transposable elements in the $D$ willistoni species, homosequential to the $P$ element of Drosophila melanogaster (Daniels et al, 1990) are in favor of the hypothesis of an invasion of Drosophila melanogaster by $P$ elements (Kidwell, 1979). This invasion could be recent and may have taken place during this century, before 1950 (Kidwell, 1983). Or it may be more ancient, but must have taken place after the divergence of the sibling species Drosophila melanogaster 
and $D$ simulans, approximately one million years ago (Engels, 1989) However, $P$ elements have homogeneous sequences, a side from internal deletions ( $O$ 'Hare and Rubin, 1983), and surveys of laboratory strains sampled on different continents since 1920 suggest that $P$ elements spread in North and South America, prior to becoming common in other parts of the world (Kidwell, 1983; Anxolabéhère et al, 1988). On the other hand, biogeographic and genetic data suggests that Drosophila melanogaster colonized the American continent only a few centuries ago, going from tropical Africa to tropical America (David and Capy, 1988).

Combined, these data suggest that $P$ elements have recently been introduced into the Drosophila melanogaster genome. This probably took place in the Americas and may have involved a neotropical species such as $D$ willistoni. Then, these elements spread into the global species, mainly by their power of transposition and presumably aided by increased human activity during the XXth century.

On the basis of the present results we propose that the $P$ element was introduced into Chinese populations of $D$ melanogaster by migration from more eastern populations. The geographical differentiation of the Eurasian populations could be due to 2 waves of $P$ element migration, one from the west and the other from the east, both coming from American populations. The molecular analysis suggests that the 2 migrations have currently stopped around the USSR-PRC frontier (between Alma-Ata and Urumqi), a high mountainous area.

When did $P$ elements occur for the first time in Chinese $D$ melanogaster populations? Because of the absence of long-established laboratory strains from this country, a retrospective temporal survey is not possible. As the current geographical distribution of $P$ elements in this area argues in favor of an invasion from the east, probably from Korean and Japanese populations, we can postulate that the $P$ elements were not introduced into Chinese populations before the end of the 1960s. Mukai et al (1985) and Choo and Lee (1986) have analyzed the temporal variations of the detrimental loads pers chromosomes in a Japanese population and in a Korean population respectively. Their results suggest that some mutator factors such as the $P$ elements may have invaded these populations at the end of the 1960s. More direct evidence for the timing of the $P$ element invasion of Japanese populations is provided by Yamamoto et al (1984): laboratory strains from Japanese natural populations were mainly of the $M$ type until 1970 . We suggest that the invasion of Chinese populations by $P$ elements took place after, or at approximately the same time, as the invasion of Korean and Japanese populations.

All presently existing natural populations of $D$ melanogaster have probably been invaded by $P$ elements. Clear quantitative and qualitative differences in $P$ element distribution between geographical regions can be observed, as a result of genetic drift, founder effects, migration, natural selection and the development of a mechanism regulating $P$ element transposition. Since the $P-M$ hybrid dysgenesis system is a manifestation of the recent introduction of $P$ elements in Drosophila melanogaster populations, it seems unlikely that any pattern seen in nature is stable. We will only be able to understand the evolution of current distributions when we have a working knowledge of the dynamics of $P$ element invasion. Although this evolution remains to be tested in nature over time, the possible mechanisms of its dynamics may be evoked. In Eurasian populations, such a mechanism might reside in the presence of $K P$ elements. The preponderance of this class of elements 
may be due to a regulatory role in hybrid dysgenesis, or to a special capacity for replicative transposition. Recent studies (Jackson et al, 1988; Périquet et al, 1989, Ronsseray el al, 1989;) provide some evidence that internally-deleted $P$ elements, in particular the $K P$ element, interact with autonomous $P$ elements and slow down or stop their spread in experimental populations. If a similar process takes place in natural populations, the high frequency of $K P$ elements in Chinese populations might "immunize" it against new invasions by autonomous $P$ elements; under these circumstances their present status in the $P-M$ system should evolve very slowly.

\section{ACKNOWLEDGMENTS}

Supported by the CNRS URA 10, Dynamique du génome et évolution; URA 1298 Biologie des populations d'insectes, PIREN (invasion) and the MEN.

\section{REFERENCES}

Anxolabéhère $\mathrm{D}$, Périquet $\mathrm{G}(1987) P$-homologous sequences in Diptera are not restricted to the Drosophilidae family. Genet Iber 39, 211-222

Anxolabéhère D, Nouaud D, Périquet G (1982) Etude de la variabilité du système $P-M$ de dysgénésie des hybrides entre populations de Drosophila melanogaster. CR Acad Sci Paris 294, 913-918

Anxolabéhère D, Kai H, Nouaud D, Périquet G, Ronsseray S (1984) The geographical distribution of $P-M$ hybrid dysgenesis in Drosophila melanogaster. Genet Sel Evol 16, 15-26

Anxolabéhère D, Nouaud D, Périquet G, Tchen P (1985) $P$ element distribution in Eurasian populations of Drosophila melanogaster: a genetic and molecular analysis. Proc Natl Acad Sci USA 82, 5418-5422

Anxolabéhère D, Kidwell MG, Périquet G (1988) Molecular characteristics of diverse populations are consistent with a recent invasion of Drosophila melanogaster by mobile $P$ elements. Mol Biol Evol 5(3), 252-269

Bingham PM, Kidwell M, Rubin GM (1982) The molecular basis of $P-M$ hybrid dysgenesis: the role of the $P$ element, a $P$ strain specific transposon family. $C e l l$ 29, 995-1004

Black DM, Jackson MS, Kidwell MG, Dover GA (1987) $K P$ elements repress $P$ induced hybrid dysgenesis in $D$ melanogaster. $E M B O J 6,4125-4135$

Boussy IA (1987) A latitudinal cline in $P-M$ gonadal dysgenesis potential in Australian Drosophila melanogaster populations. Genet Res Camb 49, 11-18

Boussy IA, Kidwell MG (1987) The $P-M$ hybrid dysgenesis cline in eastern Australia Drosophila melanogaster. Discrete $P, Q$ and $M$ region are nearly contiguous. Genetics 115, 737-745

Boussy IA, Healy MJ, Oakeshott JG, Kidwell MG (1988) Molecular analysis of the $P-M$ gonadal dysgenesis cline in Eastern Australian Drosophila melanogaster. Genetics 119, 889-902

Choo JK, Lee TJ (1986) Genetic changes in a Korean population of $D$ melanogaster $J p n J$ Genet 61, 337-343 
Daniels S, Strasbaugh LD (1986) The distribution of $P$ element sequences in Drosophila: the willistoni and saltans species group. J. Mol Evol 32, 138-148

Daniels S, Peterson KR, Strasbaugh LD, Kidwell MG, Chovnick A (1990) Evidence for horizontal transmission of $P$ transposable element between Drosophila species. Genetics 124, 339-355

David J, Capy P (1988) Genetic variation of Drosophila melanogaster natural populations. Trends Genet 4, 106-111

Engels WR (1979) Hybrid dysgenesis in Drosophila melanogaster: rules of inheritance of female sterility. Genet Res Camb 33, 219-236

Engels WR (1989) $P$ elements in Drosophila. In: Mobile DNA (Berg DE, Howe MM, ed), American Society of Microbiology, Washington, 437-484

Izaabel H, Ronsseray S, Anxolabéhère D (1987) Temporal stability of $P-M$ polymorphism in a natural population of Drosophila melanogaster. Genet Res Camb 50, 99-103

Jackson MS, Black DM, Dover GA (1988) Amplification of $K P$ elements associated with the expression of hybrid dysgenesis in Drosophila melanogaster. Genetics $120,1003-1013$

Junakovic N, Caneva R, Ballario P (1984) Genomic distribution of copia elements in laboratory stock of Drosophila melanogaster. Chromosoma (Berl) 90, 378-382

Kidwell MG, Kidwell JS, Sved JA (1977) Hybrid dysgenesis in Drosophila melanogaster : a syndrom of aberrant traits including mutation, sterility, and male recombination. Genetics $86,813-833$

Kidwell MG (1979) Hybrid dysgenesis in Drosophila melanogaster : the relationship between the $P-M$ and $I-R$ interaction system. Genet Res Camb 33, 205-217

Kidwell MG (1983) Evolution of hybrid dysgenesis determinants in Drosophila melanogaster. Proc Natl Acad Sci USA 80, 1655-1659

Kidwell MG, Frydryk T, Novy JB (1983) The hybrid dysgenesis potential of Drosophila melanogaster strains of diverse temporal and geographical natural origins. Dros Inform Serv 51, 97-100

Maniatis P, Fritsph E, Fambrook J (1982) Molecular Cloning: A Laboratory Manual. Cold Spring Harbor Lab, New-York, 545

Mukai T, Baba M, Akiyama M, Uowaki N, Kusakabe S, Tajima F (1985) Rapid change in mutation rate in a local population of $D$ melanogaster. Proc Natl Acad Sci USA 82, 7671-7675

O'Hare K, Rubin GM (1983) Structure of $P$ transposable elements and their sites of insertion and excision in the Drosophila melanogaster genome. Cell 34, 25-35

Paik YK (1988) $P$ element distribution in Korean populations of $D$ melanogaster. Genome 30, 383

Périquet G, Ronsseray S, Hamelin MG (1989) Are Drosophila melanogaster populations under a stable geographical differentiation due to the presence of $P$ elements? Heredity 63, 47-58

Ronsseray S, Lehmann M, Périquet G (1989) Comparison of the regulation of $P$ element in $M$ and $M^{\prime}$ strains of $D$ melanogaster. Genet Res Camb 54, 13-21

Tautz D, Renz M (1983) An optimized freeze-squeeze method for the recovery of DNA from agarose gels. Anal Biochem 132, 14-19 
Tchen P, Anxolabéhère D, Nouaud D, Périquet G (1985) Hybridization on squashed flies: a method to detect gene sequences in individual Drosophila. Anal Biochem $150,415-420$

Todo T, Sakoyama Y, Chigusa SI, Fukunaga A, Honjo T, Kondo S (1984) Polymorphism in distribution and structure of $P$ elements in natural populations of Drosophila melanogaster in and around Japan. Jpn J Genet 59, 441-451

Yamamoto A, Hihara F, Watanabe TK (1984) Hybrid dysgenesis in Drosophila melanogaster: predominance of $Q$ factor in Japanese populations and its change in the laboratory. Genetica $63,71-77$ 